\title{
Revisiting the Causal link Between Agriculture, Industrial output and Financial Sector Development in South Africa
}

\author{
Mabutho Sibanda ${ }^{1, *}$, Zamanguni Gumede $^{2}$, Bomi Nomlala ${ }^{3}$, Msizi Mkhize $^{4}$ and \\ Hlengiwe Ndlela ${ }^{3}$
}

\author{
${ }^{1}$ Finance, College of Law \& Management Studies, University of KwaZulu-Natal, Durban, South Africa \\ ${ }^{2}$ Taxation, College of Law \& Management Studies, University of KwaZulu-Natal, Durban, South Africa \\ ${ }^{3}$ Auditing, College of Law \& Management Studies, University of KwaZulu-Natal, Durban, South Africa \\ ${ }^{4}$ Financial Accounting, College of Law \& Management Studies, University of KwaZulu-Natal, Durban, South \\ Africa
}

\begin{abstract}
This study seeks to establish the relationship between agriculture, industrial output and financial sector development in South Africa. It uses the Autoregressive Distributed Lag, Error Correction models and Granger causality techniques to test for long- and short-run relationships. The evidence from the models indicates the presence of a longrun relationship between industrial output and agriculture, which suggests that these sectors depend on each other for raw materials and inputs. In addition, stock market development represented by market capitalization has a long-run relationship with agriculture. However, no long-run relationship is established between credit extension and agriculture; and between gross fixed capital formation and agriculture, suggesting that an increase in agricultural output does not impact investment in long-term fixed assets. The evidence also shows a long-run relationship between exports and agricultural output, which is consistent with the export-led growth hypothesis. These findings have implications for policy formulation and allocation of resources.
\end{abstract}

Keywords: Granger Causality, agricultural output, industrial output, financial development.

\section{INTRODUCTION}

This paper assesses the relationship between agriculture, industrialization and financial sector development in South Africa. South Africa has the most sophisticated and developed financial sector on the African content. It is thus imperative to establish the nexus between agriculture, industrialization and financial sector development to inform and influence policy. Most economies are arguably highly dependent on agriculture for employment, including informal selfemployment (Bruinsma, 2017; Davis, Di Giuseppe and Zezza, 2017). In addition, agriculture is an integral part of most countries' economies; inclusive growth should thus encapsulate the rural population's contributions to agriculture (Ding and Qian, 2016; Davis, Di Giuseppe and Zezza, 2017). As discussed below, it is argued both theoretically and empirically that agriculture influences economic development by positively affecting other non-agricultural sectors. We acknowledge that financial sector development has two legs - intermediary development and stock market development - and both are considered for completeness and comparison of the variables. Intermediary development captures the role played by

\footnotetext{
*Address correspondence to this author at the Finance, College of Law \& Management Studies, University of KwaZulu-Natal, Durban, South Africa; Tel: +27312602160; E-mail: sibandam@ukzn.ac.za

JEL: G10; N57; O14; O16; Q11; Q14.
}

E-ISSN: 1929-7092/19 financial institutions in lending to the private sector, while stock market development captures the financial depth of the economy (Komal and Abbas, 2015).

Agriculture contributes approximately three per cent of South Africa's Gross Domestic Product (GDP). This mainly emanates from cattle and sheep farming as only 13 per cent of the land is suitable for crop farming. However, agro-processing makes a significant contribution to the amount generated by the manufacturing sector (Stats SA, 2018). Industrial output, represented by manufacturing, contributes approximately 13 per cent of GDP. Manufacturing is largely dominated by industries like automotive, chemicals, information and communication technology, electronics, metals, textiles and clothing and footwear. The financial sector's contribution (measured as finance, real estate and business services) to GDP is approximately 22 per cent. This is the largest sector in South Africa. In this study, we use stock market capitalization and domestic credit to the private sector as a proxy for financial sector development. The descriptive statistics are provided in the findings section.

\section{LITERATURE REVIEW}

Discourse on financial development and economic development tracks back to Schumpeter (1911) who asserts that financial development is instrumental in 
economic growth. Later in 1956, Solow identifies the main drivers of economic growth as the initial levels of gross domestic product, human capital and physical capital accumulation. The relationship between financial development and industrialization has been studied before (see Goldsmith 1969; McKinnon 1973; King and Levine, 1993; Rajan and Zingales 1998; Ayyagari, Demirgüc,-Kunt, and Maksimovic, 2006). However, it remains imperative to revisit the nexus between these two sectors in the South African context given the rapid changes in both sectors.

Extant literature examines how agricultural productivity together with its associated exports led to increased economic growth through the income distribution model - a widely used economic model in macroeconomics (Galor and Zeira, 1993; Sihna, Pearson and Kadekodi, 2017). As argued by Murphy, Shleifer and Vishny (1989), theoretically, agricultural productivity is conducive for industrialization and economic development as (1) it is a source of autonomous demand for manufactured goods; and (2) income from agriculture is distributed to economic agents, resulting in increased demand for massproduced domestic goods. Empirically, agricultural productivity led to increased domestic demand and industrialization in Japan (Rosenstein-Rodan, 1943) and boosted the initial stages of industrialization in postwar Taiwan (Ranis, 1979).

However, in Japan, banks concentrated on financing agriculture, domestic commerce and international trade during this period (Patrick, 1966). Thus, according to Patrick, the demand for financial services depends on the growth of real output and monetization of agriculture; hence, the demand following and supply leading phenomena. A recent study by Obilor (2013) asserts that credit to agriculture improves agricultural productivity. However, Obilor fails to articulate how this impacts on industrialization, banking sector development and economic development. In contrast, Cucinelli (2015) argues that crises in the agricultural sector can increase the level of non-performing loans in the economy as witnessed in the United States in the late 1970s.

On the other hand, Eddine Chebbi (2010) establishes that agricultural output influences other non-agricultural sectors in the short run, although agriculture itself does not benefit from the development of commerce and the services sectors. A key finding by Eddine Chebbi is that constraints on bank credit hamper growth in agricultural output. In a regression- based study, Nnamocha and Eke (2015) confirm that bank credit and industrial output influence agricultural output in the long run. In addition, industrial output has short-run linkages with agricultural output. Bustos, Garber and Ponticelli (2016) analyzed the influence of agricultural productivity (with a focus on Genetically Engineered (GE) Soy seed) on bank deposits and credit and established that regions that engaged in GE Soy production experienced large bank deposits which did not, however, translate to increased credit by these branches. Interestingly, Bustos, Garber and Ponticelli found that bank branch networks led to increases in bank lending and larger firm growth in small to medium-size firms, which is in line with the theoretical underpinnings of Murphy, Shleifer and Vishny (1989) discussed earlier. According to Atteridge (2011), agriculture, particularly small-scale production that sustains local livelihoods, has been unattractive for private investment due to the inherent risk associated with such segments of the population. As a result, private investment has focused on large-scale export agricultural activities.

It should be noted, however, that the structure and composition of farming activities influence the impact of agricultural productivity. For instance, according to Murphy, Shleifer and Vishny (1989), in Columbia, a boom in tobacco exports in the 1850s and '60s did not lead to widespread economic development while the boom in coffee exports from 1880-1915 led to economic development. The distinguishing factor was that a few farmers planted tobacco on large tracts of land while coffee was planted on small tracts of land owned by many farmers. This subsequently led to income being widely spread among economic agents. With tobacco, a few farmers realized large amounts of income that they subsequently spent on luxury goods; hence, no economic impact was registered.

Several opportunities that arise from agricultural output have been identified by practitioners and scholars. For instance, it could result in enhanced communication and information systems (weather forecasting), off-the-grid energy, housing and construction, water management and financial services such as insurance (weather risk insurance, crop insurance and catastrophic bonds) (Pauw, 2015). Pauw concurs with the theory that agricultural output influences other economic sectors. Abbas and Choudhury (2013) further assert that agricultural output has direct causality with energy consumption, thus affirming agriculture's importance for other sectors of the economy. 
The literature on the relationship between financial development and industrial output shows that industrial output is affected by levels of interest rates and bank credit (Olokoyo, Adetiloye and Ikpefan, 2016). Welldeveloped financial systems play an important role in innovation and improvement in the profitability of investments leading to improved industrial output (Shahbaz and Lean, 2012). Ductor and Grechyna (2015:5) argue, "Financial development can decrease economic growth if it is not accompanied by development in the real sector of the economy." Consequently, financial development should influence industrial output in order to contribute to economic growth. Ductor and Grechyna call this an interdependence relationship between financial sector development and industrialization.

Evidence shows that financial sector development influences industrial output (Wang, 2000). Using stock market development as a proxy for financial development, Udegbunam (2002) shows strong evidence suggesting that financial sector development influences industrial output. Fang and Miller (2014) concur and provide overwhelming evidence that volatility in financial development leads to industrial output volatility. Gokmenoglu, Ozatac and Eren (2015) show evidence of a long run equilibrium relationship between industrialization and financial development in Turkey although Granger causality tests showed no directional causality. Neusser and Kugler (1998) on the other hand, provide evidence of no co-integration between manufacturing GDP and financial development in OECD countries. There is no consensus on how financial development, agriculture and industrialization relate to each other. The next section discusses the source of data and methodology used in this study.

\section{DATA AND METHODOLOGY}

The study uses secondary data from the McGregor BFA Library, Statistics South Africa (StatsSA) and the South African Reserve Bank (SARB) spanning 1994 (the year of the democratic transition) to September 2018. There are 99 quarterly observations for each series. A time series approach is employed for data analysis to determine whether long-run relationships exist between agricultural output and various sectors of the South African economy. The variables used are outlined below.

The main estimation variable is the natural logarithm of agricultural output (Agric). This is the primary variable under investigation and it is assumed to contain all information and output from the agricultural sector. The second variable is a proxy for industrialization, which is measured by manufacturing output $(I n d)$. The classification used by StatsSA is employed in the selection of this variable and it excludes construction. Financial development has two legs, intermediary development and stock market development, both of which are considered in this study. Intermediary development is represented by domestic credit extension to the private sector (Cred) while stock market development is represented by the JSE market capitalization (Mkt). Additional variables are included for the completeness of the estimation model below. These are gross fixed capital formation (GCF), exports (Exp), and the non-agriculture unemployment rate (UER).

The Autoregressive Distributed Lag (ARDL) cointegration technique recommended by Pesaran and Pesaran (1997), Pesaran and Shin (1998) and Pesaran, Shin and Smith (2001) is used to test for a long-run relationship between agricultural output, industrial output and financial development in South Africa. The advantage of using the ARDL estimation technique is that, unlike other techniques such as the vector error correction model, it does not require that the variables be integrated of the same order or that they be stationary or non-stationary (Hamuda, Šuliková, Gazda and Horváth, 2013; AsumaduSarkodie and Owusu, 2016). Therefore, the following basic model was estimated:

$\Delta Y_{t}=\beta_{0}+\sum_{i=1}^{n} \beta_{i} \Delta y_{t-1}+\sum_{i=0}^{n} \delta_{i} \Delta x_{t-i}+\varphi_{1} y_{t-1}+\varphi_{2} x_{t-1}+\mu_{t}$

Where: $\beta_{\mathrm{i}}$ and $\delta_{\mathrm{i}}$ are the short-run coefficients, $\varphi_{1}$ and $\varphi_{2}$ are the ARDL long-run coefficients and $\mu_{t}$ is the white noise term. The model specification based on the estimation model above is as follows:

$$
\begin{gathered}
\Delta \ln (\text { Ind }) t=\beta_{0}+\sum_{i=1}^{n} \beta_{i} \Delta \ln (\text { Ind })_{t-1}+\sum_{i=0}^{n} \delta_{i} \Delta \ln (\text { Agric })_{t-i} \\
+\varphi_{1} \ln (\text { Ind })_{t-1}+\varphi_{2} \ln (\text { Agric })_{t-1}+\mu_{t}
\end{gathered}
$$

Where: $\beta_{i}$ are the short-run coefficients with $\Delta$ as the first-difference operator. The $\varphi_{i}$ are the long-run coefficients, which were used to test for long-run causality between Agric and other variables in the series. Ind is replaced by the other variables for subsequent estimations. The estimation test hypothesis is that: 
$H_{0}: \varphi_{1}=\varphi_{2}=0$ against $H_{1}: \varphi_{1}=\varphi_{2} \neq 0$

The bounds tests can either show the presence of a long-run relationship or the absence thereof. In the case of the former, an error correction model, as specified in Equation iii below is estimated to capture the short-run dynamics of the long-run relationship such as the speed of adjustment back to equilibrium. In the case of the latter, a short-run model as specified in Equation iv is estimated.

$$
\begin{aligned}
& \Delta \ln (\text { Ind })_{t}=\vartheta_{0}+\vartheta_{1} \Delta \ln (\text { Ind })_{t-i}+\vartheta_{2} \Delta \ln (\text { Agric })_{t-i} \\
& \quad+\pi E C T_{t-i}+\varepsilon_{t}
\end{aligned}
$$

$\Delta \ln (\text { Ind })_{t}=\theta_{0}+\theta_{1} \Delta \ln (\text { Ind })_{t-i}+\theta_{2} \Delta \ln (\text { Agric })_{t-i}+\varepsilon_{t}$

Where: The lagged first differenced values on the explanatory variables show the short-run causality between Agric and Ind. To denote the long-run causality, the estimation must yield a negative and statistically significant coefficient on the ECT. The same approach is applied for Agric and the other variables. Pairwise Granger-causality tests were also estimated to augment the short-run analysis.

\section{FINDINGS}

\section{Descriptive Statistics}

Table 1 presents the results of the descriptive statistics. Average manufacturing output, domestic credit to the private sector, JSE market capitalization, gross fixed capital formation, exports and nonagricultural unemployment rate were R293 493000 , R4 453906 000, R5 478466 000, R439 489 000, R736 324000 and $24.08 \%$, respectively, when average agricultural output was R53 692 million for the period 1994 to 2018. When maximum agricultural output was R115 550 000, maximum manufacturing output, domestic credit to private sector, JSE market capitalization, gross fixed capital formation, exports and non-agricultural unemployment rate were R604 623 000, R10 740153 000, R15 294514 000, R652 624 000, R974 672000 and 29.3\%, respectively.

It is interesting to note that the non-agricultural unemployment rate increased as agricultural output increased. This is possible because the agricultural industry is becoming increasingly capital intensive and high output levels could accrue due to efficiency arising from mechanization. Table 1 also shows that most of the variables are fairly symmetrical given the skewness values of between -0.5 and 0.5 , except for the nonagricultural unemployment rate and JSE market capitalization which are moderately skewed. The nonagricultural unemployment rate is negatively skewed, suggesting very few low values on average and JSE market capitalization is positively skewed, suggesting very few high values. Overall, all the variables show that there were a few outliers from the data set. This finding is supported by the negative kurtosis measure, which shows that the data sets were light-tailed.

\section{Stationarity and Unit Root Tests}

Stationarity and unit root tests were also conducted and are shown in Table 2 . All the variables in this study were either $\mathrm{I}(0)$ or $\mathrm{I}(1)$, confirming the applicability of the ARDL model which requires that all variables are below I(2) (Arshed, 2014). Therefore, the ARDL model was used to test the long-run relationship between agricultural output and manufacturing output, domestic credit to private sector, JSE market capitalization, gross fixed capital formation, exports and the nonagricultural unemployment rate.

\section{ARDL Model Estimation}

Prior to estimating the ARDL models for Agric and the six variables, the number of optimum lags and the

Table 1: Descriptive Statistics

\begin{tabular}{|c|c|c|c|c|c|c|c|}
\hline Statistic & Agric & Cred & Exp & Ind & GCF & UER & Mkt \\
\hline \hline Mean & 53692 & 4453906 & 736324 & 293493 & 439489 & 24,08 & 5478466 \\
\hline Median & 44708 & 3746800 & 752099 & 271037 & 451850 & 24,50 & 4464192 \\
\hline Std. Dev & 26485 & 3242203 & 141425 & 143070 & 150887 & 2,77 & 4679833 \\
\hline Kurtosis & $-0,87$ & $-1,24$ & $-0,97$ & $-0,93$ & $-1,71$ & 0,31 & $-0,66$ \\
\hline Skewness & 0,49 & 0,40 & $-0,31$ & 0,38 & $-0,06$ & $-0,69$ & 0,83 \\
\hline Minimum & 15983 & 500333 & 413891 & 92269 & 209074 & 16,90 & 786248 \\
\hline Maximum & 115550 & 1074015 & 974672 & 604623 & 652624 & 29,30 & 15294514 \\
\hline
\end{tabular}


Table 2: Stationarity and Unit Root Tests

\begin{tabular}{|c|c|c|c|c|c|}
\hline \multirow{2}{*}{ ADF } & \multicolumn{2}{|c|}{$I(0)$} & \multicolumn{2}{|c|}{$I(1)$} & \multirow{2}{*}{ Ordeı } \\
\hline & C & C + @trend & C & C + @trend & \\
\hline LNAGRIC & 0.8357 & $0.0006^{\star \star *}$ & $0.0001^{* * *}$ & $0.0000^{* * *}$ & $\mathrm{I}(0)$ \\
\hline LNIND & 0.5043 & 0.4352 & $0.0000^{* * *}$ & $0.0000^{* * *}$ & $\mathrm{I}(1)$ \\
\hline LNMKT & $0.0835^{\star}$ & 0.9560 & $0.0000^{* * *}$ & $0.0000^{* * *}$ & $\mathrm{I}(1)$ \\
\hline LNCRED & 0.6253 & $0.0857^{*}$ & $0.0001^{* * *}$ & $0.0000^{* * *}$ & $\mathrm{I}(1)$ \\
\hline LNGCF & 0.4639 & 0.9222 & $0.0000^{* * *}$ & $0.0000^{* * *}$ & $\mathrm{I}(1)$ \\
\hline LNEXP & 0.4572 & $0.0239^{* *}$ & $0.0001^{* * *}$ & $0.0000^{\star \star *}$ & $\mathrm{I}(0)$ \\
\hline UER & 0.1721 & 0.2231 & $0.0000^{* * *}$ & $0.0000^{* \star *}$ & $\mathrm{I}(1)$ \\
\hline \multirow{2}{*}{ KPSS } & \multicolumn{2}{|c|}{$I(0)$} & \multicolumn{2}{|c|}{$\mathrm{I}(1)$} & \multirow{2}{*}{ Order } \\
\hline & C & C + @trend & C & C + @trend & \\
\hline LNAGRIC & $1.3206^{* * *}$ & 0.0732 & 0.1602 & $0.1601^{* *}$ & $\mathrm{I}(1)$ \\
\hline LNIND & $1.3279^{\star * *}$ & $0.2826^{\star * \star}$ & 0.2569 & 0.0593 & $\mathrm{I}(1)$ \\
\hline LNMKT & $1.2983^{* * *}$ & $0.3106^{\star \star *}$ & $0.5979^{* *}$ & 0.0418 & $\mathrm{I}(1)$ \\
\hline LNCRED & $1.3179^{* * *}$ & $0.2277^{\star \star \star}$ & 0.1564 & $0.1203^{*}$ & $\mathrm{I}(1)$ \\
\hline LNGCF & $1.2811^{* * *}$ & $0.1771^{* *}$ & 0.2999 & 0.1137 & $\mathrm{I}(1)$ \\
\hline LNEXP & $1.2511^{* \star *}$ & $0.2358^{\star \star \star}$ & 0.2394 & $0.2000^{\star *}$ & $\mathrm{I}(1)$ \\
\hline UER & $0.5182^{* *}$ & $0.1395^{\star}$ & 0.0909 & 0.0877 & $\mathrm{I}(1)$ \\
\hline
\end{tabular}

best ARDL model to estimate were determined using the SBIC, AIC and HQIC. The same procedure is also followed in the determination of the relationship between Ind and the two financial development measures - Cred and Mkt. The maximum number of lags selected was four for all six models. As shown in Table 3, ARDL $(2,0)$ was selected for Agric vs Ind, Cred, GCF and Exp. For Agric vs Mkt and UER, $\operatorname{ARDL}(4,3)$ and $\operatorname{ARDL}(1,0)$ were selected, respectively. $\operatorname{ARDL}(2,0)$ was selected for both Ind vs Cred and Ind vs Mkt. Subsequent to the confirmation of the selected models, diagnostic tests were conducted on these models. The results from the tests showed that there was no serial autocorrelation and heteroscedasticity in any of the six models. Model stability tests - CUSUM and CUSUM of squares tests - also showed that the models were stable. Therefore, the bounds tests for cointegration were subsequently conducted.

As shown in Table 4 below, based on the lower and upper bound critical values provided by Pesaran et al. (2001), the null hypothesis that there is no cointegration was rejected at $5 \%$ level of significance for Ind vs Agric, Mkt vs Agric and Exp vs Agric. All the estimated F-values (11.39496, 6.017596 and 5.943577 , respectively) were greater than the upper bound critical value (4.16). The same applies for Ind vs Cred (10.62484) and Mkt (11.70374). This suggests

Table 3: Lag length and ARDL Model Selection

\begin{tabular}{|c|c|c|c|}
\hline & Variables & Max lags & ARDL model \\
\hline \hline Model 1 & Ind vs Agric & 4 & ARDL(2,0) \\
\hline Model 2 & Cred vs Agric & 4 & ARDL(2,0) \\
\hline Model 3 & Mkt vs Agric & 4 & ARDL(4,3) \\
\hline Model 4 & GCF vs Agric & 4 & ARDL(2,0) \\
\hline Model 5 & Exp vs Agric & 4 & ARDL(2,0) \\
\hline Model 6 & UER vs Agric & 4 & ARDL(1,0) \\
\hline Model 7 & Ind vs Cred & 4 & ARDL(2,0) \\
\hline Model 8 & Ind vs Mkt & 4 & ARDL(2,0) \\
\hline
\end{tabular}


that there is a long-run relationship between Agric and these three variables as well as between Ind and the financial development measures, results that warrant the estimation of error correction models. The presence of a long-run relationship between Ind and Agric suggests that these sectors depend on each other for raw materials and inputs. Furthermore, as suggested by Murphy, Shleifer and Vishny (1989), agricultural productivity is a source of autonomous demand for manufactured goods, and income from agriculture leads to increased demand for mass-produced domestic goods. Manufacturing output thus increases to meet this demand.

The pattern seems to match those in Japan (Rosenstein-Rodan, 1943) and postwar Taiwan (Ranis, 1979). The long-run relationship is also significant for the Mkt and Agric. This is in line with Bustos, Garber and Ponticelli's finding that bank branch networks lead to increases in bank lending and larger firm growth in small- to medium-size firms that, in turn, increases market development. Furthermore, an increase in agricultural output can have an impact on agricultural derivatives trading, a component of financial markets that has grown significantly over the years. For Exp and Agric, the long-run relationship is consistent with the export-led growth hypothesis proposed by Galor and Zeira (1993) and Sinna, Pearson and Kadekodi (2017). Demand for exports may lead to the need for increased production and output in various sectors, including agriculture.

For Ind and Cred and Ind and Mkt, the significant relationship shows that financial market development contributes significantly to industrial growth and output. Per Fisman and Love (2003), financial market development enables the channelling of funds through bank lending, market-based lending and equity fundraising to support industrial development. These funds can be domestic funds from domestic savings or international funds through the foreign portfolio and foreign direct investment. The investment in plant and equipment, research and development and the expansion of businesses increase industrial output. Beck and Levine (2002) also reported that overall financial development boost industry growth, new establishment formation, and efficient capital allocation. Further, investment and development of other supportive infrastructure for industrial development usually come about as a result of proper financial market development (Demirgüç-Kunt and Levine, 2004).

For Cred vs Agric, GCF vs Agric and UER vs Agric, the null hypothesis of no long-run relationship could not be rejected at the $5 \%$ level of significance. This is because the estimated F-values (3.524962, 2.783247 and 2.849273 , respectively) were all lower than the lower bound critical value (3.62). As such, there was no need to estimate error correction models for these variables. Instead, short-run models were estimated to examine the short-run relationship between Agric and these variables. The absence of a long-run relationship between Cred and Agric matches Bustos, Garber and Ponticelli's (2016) findings. These researchers analyzed the influence of agricultural productivity on bank deposits and credit and established that regions engaged in GE Soy production experienced large bank deposits, which did not, however, translate to increased credit by these branches.

For GCF and Agric, the absence of a long-run relationship seems to suggest that an increase in agricultural output does not impact investment in longterm fixed assets. Conceivably, once-off purchases of fixed assets in the agricultural sector can increase for a

Table 4: Bounds Test for Cointegration

\begin{tabular}{|c|c|c|c|}
\hline & Estimated F-value & Lower bound & Upper bound \\
\cline { 2 - 4 } & & 3.62 & 4.16 \\
\hline \hline Ind vs Agric & 11.39496 & 3.62 & 4.16 \\
\hline Cred vs Agric & 3.524962 & 3.62 & 4.16 \\
\hline Mkt vs Agric & 6.017596 & 3.62 & 4.16 \\
\hline GCF vs Agric & 2.783247 & 3.62 & 4.16 \\
\hline Exp vs Agric & 5.943577 & 3.62 & 4.16 \\
\hline UER vs Agric & 2.849273 & 3.62 & 4.16 \\
\hline Ind vs Cred & 10.62484 & 3.62 & 4.16 \\
\hline Ind vs Mkt & 11.70374 & & \\
\hline
\end{tabular}


Table 5: Error Correction Models

\begin{tabular}{|c|c|c|c|}
\hline & Error term & t-statistic & Prob.* \\
\hline \hline Ind vs Agric & -0.502727 & -1.709457 & 0.0907 \\
\hline Mkt vs Agric & -0.081187 & -2.518478 & 0.0136 \\
\hline Exp vs Agric & -0.903287 & -3.429484 & 0.0009 \\
\hline Ind vs Cred & -0.130404 & -5.706138 & 0.0000 \\
\hline Ind vs Mkt & -0.285159 & -5.988847 & 0.0000 \\
\hline
\end{tabular}

number of years without any need for new purchases. Furthermore, the increased output may produce substantial funds, but these may be directed towards repayment of loans rather than investment in new fixed assets. For UER, it is likely that increased agricultural output comes from mechanization and capital-intensive developments such as genetic modification of seeds that do not impact on employment levels in South Africa. In addition, the increased agricultural output does not seem to be large enough to impact employment in other, non-agricultural sectors.

\section{Error Correction Models}

Error correction models were estimated for the models that yielded significant cointegrating relationships between Agric and the respective variables. Table $\mathbf{5}$ reports the results from these estimations. Similar diagnostic tests to those conducted in the ARDL estimations were again conducted before any inferences could be made from the results. All three models passed these tests. The error term coefficient was found to be negative and statistically significant in all three cases, although it was significant at $10 \%$ for the Ind vs Agric model. The results show that about $50 \%, 8 \%$ and $90 \%$ of any disequilibrium between Ind and Agric, Mkt and Agric and Exp and Agric, respectively, is corrected in each quarter. This means that a change in agricultural output would take 1.99 quarters (1/0.502727), 12.32 quarters $(1 / 0.081187)$ and 1.11 quarters (1/0.903287), respectively, for a correction back to equilibrium to occur. Thus, Exp and Ind are quick to correct back to equilibrium while Mkt is rather slow in its correction. It is conceivable given that industrial output and exports are economically more linked to agricultural output than stock market development. For Ind and Cred and Ind and Mkt, the correction to equilibrium is faster for the latter relative to the former, but the coefficients are both negative and statistically significant. It takes 7.67 quarters (1/0.130404) for Ind and Cred while it takes 3.51 quarters (1/0.285159) for Ind and Mkt to get back to equilibrium. This seems to suggest that the primary source of financing that leads to a greater form of expansion and increased industrial output is equity relative to debt, albeit both significant.

\section{Short-Run Models}

Short-run models were estimated for the variables that yielded no significant long-run cointegrating relationships with Agric, namely, Cred, GCF and UER. The results are reported in Table 6 . The diagnostic tests were also conducted on the three models and they passed all the tests. The results show that there is no significant short-run relationship between Agric and all three variables as seen by the insignificant coefficients on Agric in all three estimations. Oneperiod lagged changes in Cred and GCF influence the current values of the same variables, respectively. However, for UER, the effect is insignificant.

\section{Granger-Causality Tests}

The short-run relationship between Agric and the six variables was further examined using the Grangercausality pairwise tests. Table 7 below exhibits the results from the estimations. There is evidence that Ind, Cred, Mkt and Exp Granger-cause Agric as all the null hypotheses that these variables do not Granger-cause Agric can be rejected in favour of the alternative. However, the causality is unidirectional as the null hypothesis that Agric does not Granger-cause any of these variables cannot be rejected. This finding seems to suggest that an increase in manufacturing output, the extension of credit to the private sector, stock market development and exports all cause an increase in agricultural output.

For GCF and UER, there is no Granger-causality with Agric as none of the null hypotheses can be rejected. This suggests that an increase in agricultural output does not impact gross fixed capital formation and unemployment and vice versa. The absence of causality between agriculture and unemployment could 
Table 6: Short-Run Models

\begin{tabular}{|c|c|c|c|c|}
\hline \multicolumn{5}{|c|}{ Cred vs Agric } \\
\hline $\mathrm{D}(\mathrm{LNCRED}(-1))$ & 0.635973 & 0.077883 & -8.165754 & 0.0000 \\
\hline D(LNAGRIC $(-1))$ & 0.201337 & 0.225252 & 0.893831 & 0.3737 \\
\hline $\mathrm{D}(\mathrm{LNGCF}(-1))$ & 0.515565 & 0.087987 & 5.859569 & 0.0000 \\
\hline D(LNAGRIC $(-1))$ & 0.033637 & 0.020876 & 1.611300 & 0.1105 \\
\hline \multicolumn{5}{|c|}{ UER vs Agric } \\
\hline $\mathrm{C}$ & 0.088325 & 0.127096 & 0.694949 & 0.4888 \\
\hline
\end{tabular}

Table 7: Pairwise Granger-Causality Tests

\begin{tabular}{|c|c|c|c|}
\hline LNIND does not Granger Cause LNAGRIC & 95 & 0.0050 & Yes \\
\hline LNCRED does not Granger Cause LNAGRIC & 95 & 0.0030 & Yes \\
\hline LNAGRIC does not Granger Cause LNCRED & & 0.6312 & No \\
\hline LNGCF does not Granger Cause LNAGRIC & 95 & 0.3963 & No \\
\hline LNAGRIC does not Granger Cause LNGCF & & 0.4725 & No \\
\hline LNEXP does not Granger Cause LNAGRIC & 95 & 0.0160 & Yes \\
\hline LNAGRIC does not Granger Cause LNEXP & & 0.9779 & No \\
\hline LNIND does not Granger Cause LNMKT & & 0.0819 & Yes \\
\hline LNCRED does not Granger Cause LNIND & 95 & 0.6899 & No \\
\hline LNIND does not Granger Cause LNCRED & & 0.1169 & No \\
\hline
\end{tabular}

be due to increased capital-intensive automation in agriculture that reduces the need for labour as well as movement to jobs other than agriculture as the country becomes increasingly affluent. The lack of causality between agriculture and gross fixed capital formation could be because much investment is being channelled to the secondary and tertiary sectors rather than the primary sector under which agriculture falls.

For Ind and the two financial market development measures, the only significant causality (at $10 \%$ ) runs from Ind to Mkt. There is no evidence of causality between Ind and Cred. This is to be expected as financial market development may take longer to impact industrial output and growth. This is why there is a significant long run relationship between Ind and the two financial development measures while the short run causality is either weak or absent.

\section{CONCLUSION}

This study sought to establish the long run cointegrating relationships and short run causal linkages between agriculture, industrial output and 
financial sector development in South Africa. The evidence from the models indicates the presence of a long-run relationship between industrial output and agriculture, which suggests that these sectors depend on each other for raw materials and inputs. In addition, stock market development represented by market capitalization has a long-run relationship with agriculture. However, there is no long-run relationship between credit extension and agriculture; and between gross fixed capital formation and agriculture, suggesting that an increase in agricultural output does not impact investment in long-term fixed assets. Industrial output and growth have a significant long run relationship with financial market development measures but poor or absent short run causality linkage. This is because financial market development takes a long time to impact industrial output and growth. Future studies should consider disaggregating industrial output to determine the linkages of specific sectors with agriculture and financial sector development.

\section{REFERENCES}

Abbas F, Choudhury N. (2013). Electricity consumption-economic growth Nexus: an aggregated and disaggregated causality analysis in India and Pakistan. Journal of Policy Model, 35(4), 38-53.

https://doi.org/10.1016/j.jpolmod.2012.09.001

Asumadu-Sarkodie, S., \& Owusu, P. A. (2016). The relationship between carbon dioxide and agriculture in Ghana: A comparison of VECM and ARDL model. Environmental Science and Pollution Research, 23(11), 10968-10982. https://doi.org/10.1007/s11356-016-6252-x

Atteridge, A. (2011). Will private finance support climate change adaptation in developing countries? Historical patterns as a window on future private-sector climate finance (Working Paper No. 2011 -05: 38). Stockholm: Stockholm Environment Institute.

Awokuse, T. O., \& Xie, R. (2015). Does agriculture really matter for economic growth in developing countries? Canadian Journal of Agricultural Economics/Revue Canadienne d'agroeconomie, 63(1), 77-99. https://doi.org/10.1111/cjag. 12038

Ayyagari, M., Demirgu“c,-Kunt, A. \& Maksimovic, V. (2006). How Important Are Financing Constraints? The Role of Finance in the Business Environment. Policy Research Working Paper no. 3820, World Bank, Washington, DC.

Beck, T., \& Levine, R. (2002). Industry growth and capital allocation: Does having a market-or bank-based system matter? Journal of financial economics, 64(2), 147-180. https://doi.org/10.1016/S0304-405X(02)00074-0

Bruinsma, J. (2017). World agriculture: towards 2015/2030: an FAO study. Routledge.

Bustos, P., Garber, G., \& Ponticelli, J. (2016). Capital allocation across sectors: Evidence from a boom in agriculture. Banco Central do Brasil (414).

Cucinelli, D. (2015). The impact of non-performing loans on bank lending behaviour: evidence from the Italian banking sector. Eurasian Journal of Business and Economics, 8(16), 59-71. https://doi.org/10.17015/ejbe.2015.016.04
Davis, B., Di Giuseppe, S., \& Zezza, A. (2017). Households in Rural Africa Still Rely on Agriculture. The World Bank, $65-73$. https://doi.org/10.1596/978-1-4648-1134-0 ch8

Demirgüç-Kunt, A., \& Levine, R. (Eds.). (2004). Financial structure and economic growth: A cross-country comparison of banks, markets, and development. MIT press.

Ding, X., \& Qian, Y. (2016). Globalization, Employment and Agriculture: A Review of the Eleventh Forum of the World Association for Political Economy. World Review of Political Economy, 7(4), 541-555.

https://doi.org/10.13169/worlrevipoliecon.7.4.0541

Ductor, L., \& Grechyna, D. (2015). Financial development, real sector, and economic growth. International Review of Economics \& Finance, 37, 393-405. https://doi.org/10.1016/j.iref.2015.01.001

Eddine Chebbi, H. (2010). Agriculture and economic growth in Tunisia. China Agricultural Economic Review, 2(1), 63-78. https://doi.org/10.1108/17561371011017504

Fang, W., \& Miller, S. M. (2014). Does financial development volatility affect industrial growth volatility? International Review of Economics \& Finance, 29, 307-320. https://doi.org/10.1016/j.iref.2013.06.006

Fisman, R., \& Love, I. (2003). Trade credit, financial intermediary development, and industry growth. The Journal of finance, 58(1), 353-374. https://doi.org/10.1111/1540-6261.00527

Galor, O., \& Zeira, J. (1993). Income distribution and macroeconomics. The review of economic studies, 60(1), 3552. https://doi.org/10.2307/2297811

Gokmenoglu, K., Ozatac, N., \& Eren, B. M. (2015). The relationship between industrial production, financial development and carbon emissions: The case of Turkey. Procedia Economics and Finance, 25, 463-470. https://doi.org/10.1016/S2212-5671(15)00758-3

Goldsmith, R. W. (1969). Financial Structure and Development. New Haven, CT: Yale University Press.

Hamuda, A. M., Šuliková, V., Gazda, V., \& Horváth, D. (2013). ARDL investment model of Tunisia. Theoretical \& Applied Economics, 20(2), 23-63.

King, R, G., \& Ross, L. (1993). Finance and Growth: Schumpeter Might Be Right. Quarterly Journal of Economics, 108, 71737. https://doi.org/10.2307/2118406

Komal, R., \& Abbas, F. (2015). Linking financial development, economic growth and energy consumption in Pakistan. Renewable and Sustainable Energy Reviews, 44, 211-220. https://doi.org/10.1016/j.rser.2014.12.015

McKinnon, R. I. (1973). Money and Capital in Economic Development. Washington, DC: Brookings Institution.

Murphy, K. M., Shleifer, A., \& Vishny, R. (1989). Income distribution, market size, and industrialization. The Quarterly Journal of Economics, 104(3), 537-564. https://doi.org/10.2307/2937810

Neusser, K., \& Kugler, M. (1998). Manufacturing growth and financial development: evidence from OECD countries. Review of economics and statistics, 80(4), 638-646. https://doi.org/10.1162/003465398557726

Nnamocha, P. N., \& Eke, C. N. (2015). Bank credit and agricultural output in Nigeria (1970-2013): An error correction model (ECM) approach. British Journal of Economics. Management and Trade, 10(2), 1-12. https://doi.org/10.9734/BJEMT/2015/19884

Obilor, S. I. (2013). The impact of commercial banks' credit to agriculture on agricultural development in Nigeria: An econometric analysis. International Journal of Business, Humanities and Technology, 3(1), 85-94. 
Olokoyo, F. O., Adetiloye, K. A., \& Ikpefan, O. A. (2016). Bank's Intermediation Role and Industrial Output in Developing Economies. The Social Sciences, 11(24), 5838-5844.

Patrick, H. T. (1966). Financial development and economic growth in underdeveloped countries. Economic development and Cultural Change, 14(2), 174-189. https://doi.org/10.1086/450153

Pauw, W. P. (2015). Not a panacea: private-sector engagement in adaptation and adaptation finance in developing countries. Climate Policy, 15(5), 583-603. https://doi.org/10.1080/14693062.2014.953906

Pesaran, H. H., \& Shin, Y. (1998). Generalized impulse response analysis in linear multivariate models. Economics Letters, 58(1), 17-29. https://doi.org/10.1016/S0165-1765(97)00214-0

Pesaran, M. H., \& Pesaran, B. (1997). Working with Microfit 4.0: interactive econometric analysis; [Windows version]. Oxford University Press.

Pesaran, M. H., Shin, Y., \& Smith, R. J. (2001). Bounds testing approaches to the analysis of level relationships. Journal of applied econometrics, 16(3), 289-326. https://doi.org/10.1002/jae.616

Rajan, R. G., \& Zingales, L. 1998. Financial Dependence and Growth. American Economic Review 88, 559-87.
Schumpeter, J. (1911). Theorie der wirtschaftlichen Entwicklung (The Theory of Economic Development) (Leipzig: Duncker \& Humblot, 1911)

Shahbaz, M., \& Lean, H. H. (2012). Does financial development increase energy consumption? The role of industrialization and urbanization in Tunisia. Energy policy, 40, 473-479. https://doi.org/10.1016/j.enpol.2011.10.050

Sinha, R., Pearson, P., Kadekodi, G., \& Gregory, M. (2017). Income distribution, growth and basic needs in India. Routledge. https://doi.org/10.4324/9781315207551

Solow. R. M. (1956) A Contribution to the theory of economic growth. The Quarterly Journal of Economics, 70(1), 65-94. https://doi.org/10.2307/1884513

Udegbunam, R. I. (2002). Openness, stock market development, and industrial growth in Nigeria. The Pakistan Development Review, 69-92. https://doi.org/10.30541/v41i1pp.69-92

Wang, E. C. (2000). A dynamic two-sector model for analyzing the interrelation between financial development and industrial growth. International Review of Economics \& Finance, 9(3), 223-241. https://doi.org/10.1016/S1059-0560(99)00052-0

\section{DOI: https://doi.org/10.6000/1929-7092.2019.08.109}

(C) 2019 Sibanda et al.; Licensee Lifescience Global.

This is an open access article licensed under the terms of the Creative Commons Attribution Non-Commercial License (http://creativecommons.org/licenses/by-nc/3.0/) which permits unrestricted, non-commercial use, distribution and reproduction in any medium, provided the work is properly cited. 